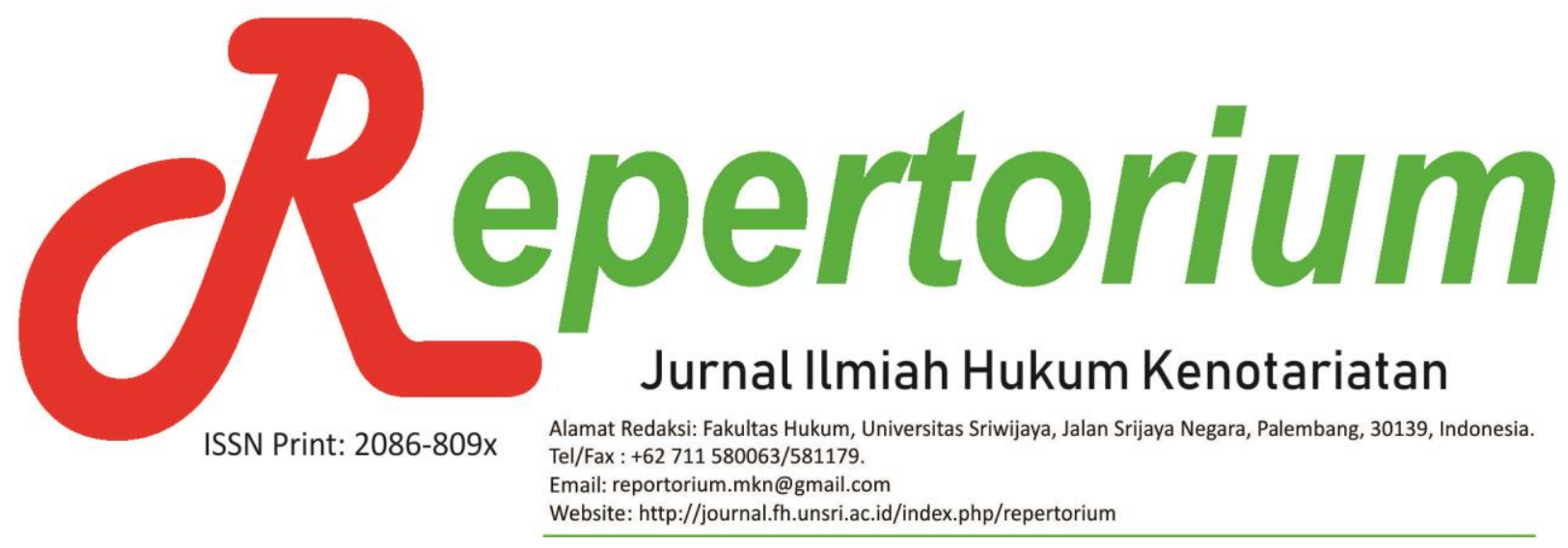

\title{
PERAN NOTARIS SEBAGAI PROFESI PENUNJANG PASAR MODAL DALAM UPAYA PERLINDUNGAN HUKUM TERHADAP INVESTOR UNTUK MENGHINDARI KERUGIAN AKIBAT PRAKTIK MANIPULASI PASAR DI PASAR MODAL
}

\begin{abstract}
Rahma Putri Prana*
Abstrak: Penelitian ini bertujuan untuk mengkaji permasalahan mengenai peran notaris dalam upaya perlindungan hukum terhadap investor agar terhindar dari kerugian akibat adanya praktik manipulasi pasar. Penelitian ini merupakan penelitian normatif yang dilakukan dengan meneliti hukum positif, aturan hukum, dan kaedah-kaedah hukum Penelitian ini menggunakan sumber-sumber penelitian yang disebut bahan hukum, baik bahan hukum primer, sekunder, maupun bahan hukum tersier, disamping itu juga menggunakan informasi sebagai penunjang yang diperoleh dari informan. Analisis dilakukan bahan penelitian dilakukan dengan metode dekriptif kualitatif yang dilakukan dengan cara menguraikan secara sistematis dari bahan pustaka dan tulisan atau kata-kata hasil wawancara dari informan untuk memperoleh hasil analisis. Berdasarkan hasil penelitian dapat disimpulkan bahwa peran notaris sebagai profesi penunjang pasar modal adalah dalam proses go public dimana notaris yang berwenang membuat dan meneliti keabsahan akta-akta atau perjanjian-perjanjian yang berkaitan dengan RUPS dan perubahan anggaran dasar. Dalam upaya untuk perlindungan hukum terhadap investor,notaris tidak berperan secara aktif, namun hanya secara pasif dimana notaris meneliti setiap keabsahan atas fakta materil dan formil dokumen-dokumen yang berkaitan dengan go public.
\end{abstract}

Kata Kunci : Investor; Manipulasi Pasar; Notaris: Perlindungan Hukum.

* Magister Kenotariatan Fakultas Hukum Universitas Sriwijaya

\section{LATAR BELAKANG}

Notaris merupakan perpanjangan tangan dari pemerintah dalam hal ini negara, di mana negara telah memberikan kepercayaan kepada notaris untuk menjalankan sebagian urusan atau tugas negara, khususnya dalam bidang hukum perdata.
Notaris adalah pejabat publik dengan satu-satunya wewenang untuk membuat akta kesepakatan kontrak atau keputusan dengan yang diharuskan oleh hukum untuk diformulasikan dalam dokumen yang dikonfirmasi. notaris juga bertanggung jawab untuk mengatur tanggal akta, untuk menyimpan untuk memberikan grosse yang sah atau salinan atau kutipan sebagian dari perbuatan, asalkan pembuatan 
akta tidak ditugaskan kepada pejabat publik lainnya dan hanya tugas eksklusif dari notaris.

Pasal 1 angka 1 Undang-undang Republik Indonesia nomor 02 tahun 2014 tentang Perubahan atas Undang-undang Republik Indonesia Nomor 30 Tahun 2004 tentang Jabatan Notaris (selanjutnya di sebut UUJN), menyatakan bahwa yang dimaksud dengan Notaris adalah pejabat umum yang berwenang untuk membuat akta autentik dan memiliki kewenangan lainnya sebagaimana dimaksud dalam Undang-undang ini atau berdasarkan undangundang lainnya.

Menurut Pasal 15 Undang-Undang Nomor 30 Tahun 2004 tentang Jabatan Notaris (selanjutnya disebut UUJN) berbunyi : "Notaris berwenang membuat akta otentik mengenai semua perbuatan, perjanjian, dan ketetapan yang diharuskan oleh peraturan perundang-undangan dan/atau yang dikehendaki oleh yang berkepentingan untuk dinyatakan dalam akta otentik, menjamin kepastian tanggal pembuatan akta, menyimpan akta, memberikan grosse, salinan dan kutipan akta, semuanya itu sepanjang pembuatan akta-akta itu tidak juga ditugaskan atau dikecualikan kepada pejabat lain atau orang lain yang ditetapkan oleh undang-undang."

Kewenangan pokok dari notaris berdasarkan UUJN adalah membuat akta otentik. Akta sebagai surat bukti yang sengaja diadakan sebagai alat pembuktian, dalam zaman yang semakin maju akan semakin penting mengingat fungsi akta sebagai dokumen tertulis yang dapat memberikan bukti akan peristiwa hukum yang menjadi dasar dari hak atau perikatan.

Selain kewenangan pokok tadi, notaris juga diberikan kewenangauntuk memberikan penyuluhan hukum terhadap pihakpihak yang terlibat dalam suatu transaksi, khususnya mengenai syarat-syarat dan ke- tentuan yang harus dipenuhi oleh seluruh pihak di dalam suatu transaksi yang akan di notarilkan, sehingga tidak atau terhindar dari kemungkinan transaksi tersebut dilaksanakan dengan keadaan yang batal demi hukum atau dapat dimintakan pembatalan di depan pengadilan. Kewenangan memberikan penyuluhan hukum ini diinterpretasikan dari Pasal 15 ayat (2) huruf f UUJN yang berbunyi : "Notaris berwenang pula memberikan penyuluhan hukum sehubungan dengan pembuatan akta"

Oleh Undang-undang Pasar Modal, profesi notaris telah ditunjuk sebagai salah satu profesi penunjang pasar modal. peran utama profesi penunjang pasar modal pada umumnya adalah membantu emiten dalam proses go public dan memenuhi persyaratan mengenai keterbukaan (disclousure) yang sifatnya terus. Penunjukkan Notaris sebagai profesi penunjang pasar modal dinyatakan dalam, pasal 64 ayat 1 UndangUndang Nomor 8 Tahun 1995 tentang Pasr Modal ( selanjutnya disebut UUPM), yang menyatakan profesi penunjang pasar modal terdiri dari :

1) Akuntan;

2) Konsultan Hukum;

3) Penilai;

4) Notaris; dan

5) Profesi lain yang ditetapkan dengan Peraturan Pemerintah."

Setiap Profesi Penunjang Pasar Modal termasuk notaris wajib menaati kode etik dan standar profesi yang ditetapkan oleh asosiasi profesi masing-masing sepanjang tidak bertentangan dengan UUPM dan atau peraturan pelaksanaannya. Dalam melakukan kegiatan usaha di bidang Pasar Modal, notaris wajib memberikan pendapat atau penilaian yang independen.

Pasar modal sebagai wadah untuk mencari dana bagi perusahaan dan alternatif sarana investasi bagi masyarakat (investor) dimana di dalamnya terdapat transaksi 
penawaran umum dan perdagangan efek dari perusahaan publik (emiten) kepada masyarakat investor. Pasar Modal/Capital Market/Stock Exchange/Stock Marketl dalam pengertian klasik diartikan sebagai suatu bidang usaha perdagangan surat-surat berharga seperti saham, sertifikat saham, dan obligasi atau efek-efek pada umumnya. Pasal 1 angka 13 Undang-Undang Nomor 08 Tahun 1995 tentang Pasar Modal memberikan pengertian pasar modal yang lebih spesifik, yaitu kegiatan yang bersangkutan dengan penawaran umum dan perdagangan efek, perusahaan publik yang berkaitan dengan efek yang diterbitkannya, serta lembaga dan profesi yang berkaitan dengan efek. Kegiatan tersebut dilindungi oleh payung hukum yang sangat menjunjung tinggi prinsip keterbukaan. Penentuan harga di Pasar Modal dipengaruhi oleh suatu informasi atau fakta materil, karena suatu informasi mencerminkan suatu harga. Dalam Pasal 1 angka 7 Undang-Undang Nomor 8 Tahun 1995, yang dimaksud dengan informasi atau fakta materil adalah informasi atau fakta penting dan relevan mengenai peristiwa, kejadian, atau fakta yang dapat mempengaruhi harga Efek pada Bursa Efek dan atau keputusan pemodal, calon pemodal, atau pihak lain yang berkepentingan atas informasi atau fakta tersebut. Informasi yang harus disampaikan kepada publik adalah informasi yang akurat dan lengkap sesuai dengan keadaan perusahaan. Prinsip keterbukaan adalah prinsip yang menjadi landasan pertimbangan bagi para pelaku di pasar modal untuk melakukan aktivitas perpasarmodalan secara rasional. Menurut Peraturan Nomor X.K.1. IV-1. Keputusan Ketua Badan Pengawas Pasar Modal. Suatu informasi merupakan fakta materiil bila informasi tersebut dapat mempengaruhi turun naiknya harga saham. Karena itu, untuk menjual saham pada pasar primer dan pasar sekunder, manajemen perusahaan harus menjaga pasar. Artinya semua informasi yang relevan mengenai apa yang ada dan akan ada harus dikemukakan. Jika tidak investor akan kehilangan kesempatan menjual sahamnya.

Dengan dinyatakan efektif pernyataan pendaftaran (listing), maka emiten mempunyai kewajiban untuk selalu menyampaikan informasi penting yang berbentuk laporan berkala dan laporan kejadian penting di pasar sekunder (setelah listing).

Hal ini dilakukan agar tidak terjadi kejahatan-kejahatan pasar yang dapat merugikan investor, khususnya rekayasa pasar atau bisa juga disebut sebagai manipulasi pasar. Pasal 91 Undang-undang tentang Pasar Modal menyebutkan :

"Setiap pihak dilarang melakukan tindakan, baik langsung maupun tidak langsung, dengan tujuan untuk menciptakan gambaran semua atau menyesatkan mengenai kegiatan perdagangan, keadaan pasar, atau harga efek di Bursa Efek."

Adapun beberapa kasus kejahatan pasar modal yang terjadi di Indonesia adalah Sarijaya Permana Sekuritas yang terjadi pada tahun 2009, Antaboga Delta Sekuritas pada tahun 2008, Signatuter Capital Indonesia pada tahun 2006, AAA Sekuritas, serta PT. Sekawan Inti Pratama pada Tahun 2015. Semua kasus kejahatan tersebut sangat merugikan investor.

Pada faktanya, semua perlindungan yang diberikan oleh hukum belum sepenuhnya menjamin kemanan investor dalam 

berinvestasi di dunia pasar modal. Khususnya perlindungan mengenai keamanan saham para investor. Investor pasti merasa dirugikan karena dana yang mereka tanamkan dengan membeli saham perusahaan yang ditawarkan ternyata membawa kerugian bagi mereka. Kita mengetahui bahwa berinvestasi di pasar modal khususnya saham mengandung resiko yang tinggi (high risk). Akibat adanya high risk tersebut, maka hukum dituntut memberi jaminan dan keamanan pada investor saham dalam bertransaksi di dunia pasar modal.

Terlebih saat ini tidak ada Undangundang yang secara khusus mengatur dengan tegas tentang penjaminan serta perlindungan hukum bagi investor agar tenang dalam menanamkan sahamnya di perusahaan publik tersebut.

Hal ini menjadi pekerjaan rumah yang cukup berat bagi Bursa Efek Indonesia (BEI) sebab proses pendaftaran ternyata tidak menjamin bahwa perusahaan tersebut dijamin liquiditasnya. Peranan hukum pun mulai dipertanyakan dalam hal perlindungan hukum bagi para investor saham, sebab emiten yang melakukan manipulasi pasar dapat merugikan investor.

Permasalahan yang dibahas dalam penelitian ini dapat dirumuskan sebagai berikut : Pertama, bagaimana upaya perlindungan hukum terhadap investor untuk menghindari kerugian akibat praktik manipulasi pasar di pasar modal Indonesia ? Kedua, bagaimanakah peran notaris sebagai profesi penunjang pasar modal dalam upaya melindungi investor agar terhindar dari kerugian akibat praktik manipulasi pasar ?

\section{METODE}

Jenis penelitian yang digunakan adalah penelitian hukum normatif . Penelitian yang dilakukan ini merupakan penelitian pustaka (library research), yaitu suatu penelitian yang sumber datanya diperoleh dari pustaka, buku-buku atau kary-karya tulis yang relevan dengan pokok permasalahan yang diteliti dengan pendekatan. Penelitian ini menggunakan pendekatan perundangundangan (statute approach) dengan jenis dan sumber bahan penelitian diperoleh dari data sekunder yang terdiri dari bahan hukum primer, sekunder dan tersier, serta didukung data empiris melalui tekhnik wawancara.

Pengumpulan bahan penelitian dilakukan berdasarkan studi kepustakaan. Analisis data dilakukan dengan cara interpretasi data sebatas pada masalah penelitian yang diteliti berdasarkan data yang dikumpulkan dan diolah untuk keperluan penelitian tersebut.

Penelitian ini dianalisis secara deskriptif analitis, yaitu mencari dan menentukan hubungan antara data yang diperoleh dari penelitian dengan landasan teori yang ada yang dipakai sehingga memberikan gambaran-gambaran konstruktif mengenai permasalahan yang diteliti. Disamping itu digunakan juga metode analisa yang kualitatif dengan tujuan untuk mengerti atau memahami gejala yang diteliti.

\section{ANALISIS DAN DISKUSI}

1. Upaya Perlindungan Hukum Terhadap Investor Untuk Menghindari Kerugian Akibat Praktek Manipulasi Pasar Perlindungan hukum terhadap investor dilaksanakan berdasarkan prinsip adanya jaminan pemerintah agar investor dapat memperoleh informasi dan faktor-faktor yang dijadikan pertimbangan dalam pengambilan keputusan investasi. Prinsip ini menjiwai Undang-undang Pasar Modal. Hal ini berlangsung sejak sebelum maupun sesudah emiten go publik. Bentuk perlindungan tersebut dilakukan melalui:

1) Menyatakan pendaftaran 
Pernyataan pendaftaran terdiri dari seluruh informasi yang harus dikemukakan kepada publik. Pernyataan pendaftaran menjadi efek apabila Bapepan mempertimbangkan bahwa seluruh informasi diungkapkan dan dipandang cukup. Pernyataan pendaftaran bertanggung jawab penuh terhadap kelengkapan informasi yang disajikan. Bagian pernyataan pendaftaran yang disebut prospektus harus disebarkan kepada masyarakat pada saat penawaran umum. Hal ini diatur dalam Pasal 70 sampai dengan Pasal 19

2) Continuing Disclosure. Perlindungan kepada investor tidak hanya diberikan melalui pernyataan pendaftaran bagi emiten akan tetapi setelah penawaran umum dinyatakan efektif, emiten tetap harus menyampaikan informasi secara terus menerus dan fakta-fakta yang penting dan relevan yang menyangkut kejadian-kejadian dalam perusahaan yang dapat mempengaruhi keputusan investor. Informasi yang perlu diungkapkan kepada masyarakat investor terbagi dua, yaitu laporan keuangan tahunan dan tengah tahunan dan informasi non keuangan. Pedoman penyusunan laporan keuangan tahunan dan tengah tahunan diatur dalam lampiran surat edaran Bapepam No. Ws24/PM/ 1987 tanggal 24 Desember 1987. Selain itu emiten wajib mengumumkan neraca dan perhitungan rugi laba pada sekurang-kurangnya dua surat khabar berbahasa salah satunya mempunyai peredaran $\mathrm{Na}-$ sional. Ketentuan diatur dalam Pasal 80-81.

3) Informasi Penting dan Relevan Lainnya. Informasi lain yang bersifat non keuangan yang juga harus diikuti oleh investor adalah kejadian atau informasi penting yang relevan yang mungkin dapat mempengaruhi nilai efek perusahaan atau keputusan para investor. Bapepam mengatur hal ini lampiran Keputusan Ketua
Bapepam No. Kep-22/PM/1991 tanggal 19 April 1991.

Keterangan-keterangan penting yang dapat mempengaruhi nilai efek atau keputusan para investor antara lain penggabungan usaha (merger), pembelian saham (acquisition), peleburan usaha (consolidation) atau pembentukan usaha patungan dan lain-lain yang bentuknya ditentukan oleh Bapepam kurang lebih 14 kejadian penting. 4) Kecukupan Informasi

Informasi yang diharapkan Investor adalah informasi yang benar dan memadai, tetapi biasanya informasi yang disampaikan emiten masih berupa informasi yang masih perlu dianalisis. Oleh karena itu investor dapat meminta nasihat dari perusahaan efek atau penasihat investasi. Setiap keterlambatan informasi dikenakan denda antara Rp. 100.000 sampai dengan Rp. 500 juta.

\section{Upaya Perlindungan Hukum Preventif}

Untuk melindungi investor maka pihak emiten yang akan menjual efek dalam Penawaran Umum harus memberikan kesempatan kepada investor untuk membaca prospektus berkenaan dengan efek yang diterbitkan, sebelum pemesanan ataupun pada saat pemesanan dilakukan. Pada akhirnya setelah OJK memperhatikan kelengkapan dan kejelasan dokumen emiten untuk melakukan Penawaran Umum demi memenuhi prinsip keterbukaan pasar modal. Hal ini penting mengingat prospektus atas efek merupakan pintu awal dan waktu untuk mempertimbangkan bagi investor apakah akan memutuskan membeli atau tidak atas suatu efek.

Tindakan pencegahan selanjutnya yang dilakukan oleh OJK adalah mengatur bahwa prospektus efek dilarang memuat konten menyesatkan atau keterangan yang tidak benar tentang Fakta Material atau menyajikan informasi tentang kelebihan dan kekurangan efek yang ditawarkan. Da 
lam praktiknya OJK membuat standar penyusunan prospektus atas efek yang akan ditawarkan. Tindakan perlindungan ini dimulai pada saat OJK memberikan izin terhadap SRO, Reksadana, perusahaan efek, maupun profesi-profesi penunjang untuk berkegiatan di pasar modal.

Bursa Efek Indonesia (BEI) merupakan pihak yang menyelenggarakan dan menyediakan sistem untuk mempertemukan penawaran jual dan beli efek pihak-pihak lain dengan tujuan memperdagangkan efek di antara mereka.

Selain sebagai penyelenggara, BEI juga memiliki peranan dala hal mencegah terjadinya kejahatan-kejahatan pasar khususnya manipulasi pasar yang dapat merugikan investor.

Pada dasarnya baik itu BEI atau pun OJK tidak menjamin bahwa perusahaan yang telah dicatatkan di BEI dan diawasi oleh OJK itu sepenuhnya aman, hal ini dikarenakan yang menjadi dasar dari BEI dan OJK adalah pemenuhan persyaratan minimum perusahaan go public agar dipenuhi, yang terdiri dari :

1. Keterbukaan informasi baik itu secara rutin yakni tentang laporan keuangan ataupun yang tidak rutin

2. Perusahaan tersebut harus melaksanakan RUPS

3. Melaksanakan Public Expose yang artinya Suatu pemaparan umum kepada publik untuk menjelaskan mengenai kinerja Perusahaan Tercatat dengan tujuan agar informasi mengenai kinerja perusahaan tersebut tersebar secara merata, baik itu secara rutin yang dilakukan setiap tahunnya maupun yang tidak rutin dapat berupa informasi saham yang suatu saat bergerak tidak normal ataupun hal yang berkaitan dengan informasi simpang siur yang beredar dimasyarakat.
Membahas tentang perlindungan hukum investor maka erat kaitannya dengan perdagangan efek, maka dari itu BEI juga melakukan tindakan preventif dengan mengawasi setiap pergerakan kegiatan saham atau efek perusahaan tersebut dan juga melakukan tindakan preventif tambahan agar investor tidak mengalami kerugian yaitu berupa :

1. Unusual Market Activity (UMA) yaitu aktifitas perdagangan dan/atau pergerakan harga suatu Efek yang tidak biasa pada suatu kurun waktu tertentu di Bursa yang menurut penilaian Bursa dapat berpotensi mengganggu terselenggaranya perdagangan efek yang teratur, wajar dan efisien. Berita tentang adanya UMA akan di informasikan di situs resmi BEI yang dapat diakses oleh setiap orang dan diperbaharui setia hari. Pengumuman UMA tidak serta merta menunjukkan adanya pelanggaran dibidang pasar modal yang dilakukan oleh perusahaan tersebut.

2. Efek Tidak Dijamin (ETD) yaitu Efek yang ditetapkan oleh Bursa Efek dan Lembaga Kliring dan Penjaminan berdasarkan persyaratan tertentu yang penyelesaian transaksinya tidak dijamin sebagaimana diatur dalam Pasal 1 Angka 11 Peraturan Otoritas Jasa Keuangan Nomor 26/POJK.04/2014 Tentang Penjaminan Penyelesaian Transaksi Bursa. Dalam hal terjadinya transaksi bursa atas efek tidak dijamin maka lembaga kliring dan penjamin tidak melakukan penjaminan penyelesaian transaksi bursa terhadap transaksi bursa atas efek tidak dijamin yang artinya lembaga kliring dan penjamin tidak bertanggung jawab atas kerugian yang di alami setiap pihak sebagai akibat keterlambatan dalam penyelesaian transaksi bursa yang tidak dijaminnya.

3. Transaksi Dipisahkan (TD)yaitu Transaksi Bursa yang dipisahkan dari Penjaminan Penyelesaian Transaksi Bursa ber- 
dasarkan ketentuan yang ditetapkan oleh Bursa Efek dan Lembaga Kliring dan Penjaminan atau atas perintah Otoritas Jasa Keuangan sebagaimana diatur dalam Pasal 1 Angka 10 Peraturan Otoritas Jasa Keuangan Nomor 26/POJK.04/2014 Tentang Penjaminan Penyelesaian Transaksi Bursa.

4. Suspensi yaitu pemberhentian sementara aktivitas efek terhadap perusahaan yang telah lalai menyampaikan laporan keuangan kepada BEI dan telah melampaui batas waktu yang diberikan.

Upaya Perlindungan Hukum Represif.

Yaitu dalam bentuk pemeriksaan, penyidikan dan penerapan sanksi-sanksi. Apabila terjadi pelanggaran di bidang pasar modal, maka OJK berwenang untuk melakukan pemeriksaan dan penyidikan seperti yang disebutkan pada bunyi pasal 9 UU OJK huruf c :

“...Untuk melakukan tugas pengawasan sebagaimana dimaksud dalam pasal 6 , OJK mempunyai wewenang melakukan pengawasan, pemeriksaan, penyidikan, perlindungan konsumen, dan tindakan lain terhadap lembaga jasa keuangan, pelaku, dan/atau penunjang kegiatan jasa keuangan sebagaimana dmaksud dalam peraturan perundang-undangan disektor jasa keuangan."

Selain melakukan pemeriksaan dan penyidikan OJK juga memiliki wewenang untuk menetapkan sanksi sebagaimana yang dijelaskan oleh pasal 8 huruf I UU OJK yang berbunyi :

"untuk melaksanakan tugas pengaturan sebagaimana dimaksud dalam pasal 6 , OJK mempunyai wewenang menetapkan peraturan mengenai tata cara pengenaan sanksi sesuai dengan ketentuan peraturan perundang-undangan di sektor jasa keuangan"

Lebih lanjut BEI memberikan jalan bagi investor untuk mendapatkan ganti rugi apabila hal tersebut telah terjadi melalui pembentukan Dana Perlindungan Pemodal oleh
Indonesia Securities Investor Protection Fund, melalui tahap-tahap berikut ini:

1. Tahapan Perlindungan

Baik dalam segi aset yang dilindungi maupun dalam segi pemodal yang akan dilindungi, terdapat beberapa tahapan perlindungan sebagai berikut:

1 Januari 2014 - 31 Desember 2015

Dana Perlindungan Pemodal hanya memberikan ganti rugi kepada Pemodal yang merupakan nasabah Perantara Pedagang Efek yang mengadministrasikan rekening Efek nasabah dan Anggota Bursa Efek PT Bursa Efek Indonesia. Terhadap Aset Pemodal, pemberian ganti rugi tersebut hanya terbatas pada Aset Pemodal berupa saham yang masuk dalam Penitipan Kolektif LPP dan dicatatkan pada BEI. 1 Januari 2016

Dana Perlindungan Pemodal hanya memberikan ganti rugi kepada Pemodal yang merupakan nasabah Perantara Pedagang Efek yang mengadministrasikan rekening Efek nasabah dan Anggota Bursa Efek PT Bursa Efek Indonesia dan yang merupakan nasabah Bank Kustodian. Terhadap Aset Pemodal, Dana Perlindungan Pemodal memberikan ganti rugi kepada Pemodal yang merupakan nasabah Bank Kustodian. Pemberian ganti rugi pada Aset Pemodal berupa Dana yang mendapat perlindungan Dana Perlindungan Pemodal adalah Dana yang dititipkan pada Kustodian yang dibukakan Rekening Dana Nasabah pada Bank atas nama masing-masing Pemodal.

2. Tahapan Penanganan Klaim Penyelenggara Dana Perlindungan Pemodal melakukan kegiatan penanganan klaim Pemodal yang kehilangan Aset Pemodal setelah OJK menyatakan terdapat kondisi :

1) Terdapat kehilangan Aset Pemodal 
2) Kustodian tidak memiliki kemampuan untuk mengembalikan Aset Pemodal yang hilang

3) Bagi Kustodian berupa Perantara Pedagang Efek yang mengadministrasikan Efek dinyatakan tidak dapat melanjutkan kegiatan usahanya dan dipertimbangkan izin usahanya dicabut oleh OJK; atau

4) Bagi Bank Kustodian dinyatakan tidak dapat melanjutkan kegiatan usahanya sebagai Bank Kustodian dan dipertimbangkan persetujuan Bank Umum sebagai Kustodian dicabut oleh OJK.

Dalam waktu paling lambat 3 (tiga) hari kerja setelah menerima penetapan dari OJK, Direksi Penyelenggara Dana Perlindungan Pemodal wajib:

1. Mengumumkan ke masyarakat melalui surat kabar / media lainnya jika terjadi peristiwa dimaksud di atas dan mengundang Pemodal terkait agar menyampaikan klaim kepada Penyelenggara Dana Perlindungan Pemodal dalam waktu tidak lebih dari 30 (tiga puluh) hari kerja sejak pengumuman dilakukan

2. Mengusulkan pembentukan komite klaim kepada OJK; dan

3. Membentuk tim verifikasi klaim.

Ganti Rugi Kepada Investor

Pembayaran ganti rugi kepada Pemodal dengan menggunakan Dana Perlindungan Pemodal dilakukan jika memenuhi ketentuan sebagai berikut:

OJK telah menerbitkan pernyataan tertulis bahwa:

1. Terdapat kehilangan Aset Pemodal

2. Kustodian tidak memiliki kemampuan untuk mengembalikan Aset Pemodal yang hilang; dan

3. Bagi Kustodian berupa Perantara Pedagang Efek yang mengadministrasikan Efek dinyatakan tidak dapat melanjutkan kegiatan usahanya dan dipertimbangkan izin usahanya dicabut oleh OJK; atau

4. Bagi Bank Kustodian dinyatakan tidak dapat melanjutkan kegiatan usahanya sebagai Bank Kustodian dan dipertimbangkan persetujuan Bank Umum sebagai Kustodian dicabut oleh OJK.

Pemodal telah mengajukan permohonan ganti rugi kepada Penyelenggara Dana Perlindungan Pemodal sesuai dengan Peraturan OJK Nomor VI.A.5 tentang Penyelenggara Dana Perlindungan Pemodal

Ganti rugi sebagaimana dimaksud diberikan dalam bentuk dana sebesar nilai Aset Pemodal yang hilang dan/atau sesuai dengan batasan paling tinggi untuk setiap Pemodal dan setiap Kustodian yang ditetapkan oleh OJK. Ganti rugi atas nilai Aset Pemodal yang hilang tidak mencakup nilai kerugian atas perkiraan nilai investasi masa datang. Besaran ganti rugi aset pemodal adalah Rp 100 juta per Pemodal, dan Rp 50 miliar per Kustodian.

Selanjutnya perlindungan yang bersifat represif dapat dilakukan melalui penerapan Sanksi pidana terhadap pelaku kejahatan yang diatur dalam UU Pasar Modal. Setelah OJK melakukan pemeriksaan dan penyidikan maka diberikan sanksi sesuai dengan ketentuan peraturan perundangundangan.

Notaris adalah bentuk wujud atau perwujudan dan merupakan personifikasi dari hukum keadilan, kebenaran, bahkan merupakan jaminan adanya kepastian hukum bagi masyarakat. Kedudukan seorang notaris sebagai suatu fungsionaris dalam masyarakat hingga sekarang masih disegani. Seorang notaris biasanya dianggap sebagai seorang pejabat tempat sesorang dapat memperoleh nasehat yang dapat diandalkan. Segala sesuatu yang ditulis serta ditetapkan adalah benar. Ia ada- 
lah pembuat dokumen yang kuat dalam suatu proses hukum.

Keberadaan notaris dalam industri pasar modal diatur dalam Pasal 64 UUPM. Dan sebagai salah satu pelaku di pasar modal, profesi penunjang pasar modal turut berperan sekaligus bertanggung jawab dalam mengembangkan industri pasar modal. Peran notaris di bidang pasar modal diperlukan terutama dalam hubungannya dengan penyusunan Anggaran Dasar dan perubahan anggaran dasar pelaku pasar modal seperti emiten, perusahaan publik, perusahaan efek serta kontrak-kontrak penting seperti Kontrak Insvestasi Kolektif (KIK), kontrak penjaminan emisi atau akta penting seperti Akta Pembubaran Dan Likuidasi Reksa Dana.

Jasa Notaris sebagai profesi penunjang pasar modal, dalam aktivitas pasar modal, diperlukan pula dalam hal-hal antara lain :

1. Membuat berita acara Rapat Umum Pemegang Saham (RUPS) dan menyusun pernyataan keputusan RUPS, baik untuk persiapan go public maupun RUPS setelah go public.

2. Meneliti keabsahan hal-hal yang menyangkut penyelenggaraan RUPS, seperti kesesuaian dengan anggaran dasar perusahaan, tata cara pemanggilan untuk RUPS dan keabsahan dari pemegang saham atau kuasanya untuk menghadiri RUPS.

3. Meneliti perubahan anggaran dasar tidak terlepas materi pasal-pasal dari anggaran dasar yang bertentangan dengan peraturan perundang-undangan yang berlaku. Bahkan diperlukan untuk melakukan penyesuaian-penyesuaian pasal-pasal dalam anggaran dasar agar sejalan dan memenuhi ketentuan menurut peraturan di bidang pasar modal dalam rangka melindungi investor dan mayarakat. .

Di samping itu peranan notaris di pasar modal juga diperlukan, terutama dalam penyusunan anggaran dasar para pelaku pasar modal seperti emiten, perusahaan publik, perusahaan efek, dan reksadana.

Pasal 1 angka 1 UUJN menyatakan "Notaris adalah pejabat umum yang berwenang untuk membuat akta otentik dak kewenangan lainnya sebagaimana dimaksud dalam undang-undang ini."

Dalam menjalankan jabatannya notaris memiliki wewenang yang diatur oleh UUJN yang isinya menyatakan "Notaris berwenang membuat akta otentik mengenai semua perbuatan, perjanjian, dan ketetapan yang diharuskan oleh peraturan perundangundangan dan/atau yang dikehendaki oleh yang berkepentingan untuk dinyatakan dalam akta otentik, menjamin kepastian tanggal pembuatan akta, menyimpan akta, memberikan grosse, salinan dan kutipan akta, semuanya itu sepanjang pembuatan akta-akta itu tidak juga ditugaskan atau dikecualikan kepada pejabat lain atau orang lain yang ditetapkan oleh undang.undang." Dalam pasal 1 angka 20 UUPM, dinyatakan bahwa yang dimaksud dengan perseroan terbatas sebagaimana dimaksud dalam Pasal 1 angka 1 UUPT adalah badan hukum yang merupakan persekutuan modal, didirikan berdasarkan perjanjian, melakukan kegiatan usaha dengan modal dasar yang seluruhnya terbagi dalam saham dan memenuhi persyaratan yang ditetapkan dalam undangundang PT serta peraturan pelaksanaannya. Dalam pendirian Perseroan Terbatas, notaris menurut Pasal 7 ayat (1) dinyatakan bahwa Perseroan didirikan oleh 2 (dua) orang atau lebih dengan akta notaris yang dibuat dalam bahasa Indonesia.

Jika aspek formal dan materil dipermasalahkan oleh pihak lain, maka pihak yang merasa dirugikan tersebut harus melakukan pembuktian terbalik untuk menyangkal kebenaran aspek formal dan 
materil dari akta notaris tersebut. Pihak yang merasa dirugikan harus dapat membuktikan ketidakbenaran hari, tanggal, bulan, tahun, dan pukul (waktu) menghadap, serta membuktikan ketidakbenaran mereka yang menghadap atau membuktikan bahwa notaris tidak menerangkan atau menyatakan yang sebenarnya dalam akta sesuai dengan pernyataan atau keterangan para penghadap pada saat pembuatan akta.

Manipulasi pasar merupakan salah satu kejahatan yang dapat terjadi dalam pasar modal. Larangan tentang praktik Manipulasi pasar sendiri di nyatakan dalam pasal 91 UUPM dimana Setiap Pihak dilarang melakukan tindakan, baik langsung maupun tidak langsung, dengan tujuan untuk menciptakan gambaran semu atau menyesatkan mengenai kegiatan perdagangan, keadaan pasar, atau harga Efek di Bursa Efek, dengan tujuan untuk menarik investor agar membeli efek atau saham diperusahaan tersebut.

Setiap Pihak dilarang, dengan cara apa pun, membuat pernyataan atau memberikan keterangan yang secara material tidak benar atau menyesatkan sehingga mempengaruhi harga Efek di Bursa Efek apabila pada saat pernyataan dibuat atau keterangan diberikan:

1) Pihak yang bersangkutan mengetahui atau sepatutnya mengetahui bahwa pernyataan atau keterangan tersebut secara material tidak benar atau menyesatkan; atau

2) Pihak yang bersangkutan tidak cukup berhati-hati dalam menentukan kebenaran material dari pernyataan atau keterangan tersebut.

Pada dasarnya notaris memiliki peran yang sangat vital walaupun tidak secara langsung dan bersifat preventif (pencegahan), berikut peran notaris dalam upaya melindungi investor:
1. Pada saat ada perusahaan yang akan go public atau go privat. Notaris memang tidak bertanggung jawab secara langsung terhadap perlindungan investor, tetapi dengan perannya dan tanggung jawabnya dengan hadir dan dalam meneliti keabsahan mengenai hal-hal menyangkut penyelanggaraan go public dan RUPS, maka notaris tersebut secara tidak langsung telah berkontribusi dalam mencegah terjadinya kejahatan pasar modal.

2. Berkaitan dengan informasi kepada masyarakat dalam hal ini investor tentang laporan keuangan. Perusahaan yang telah go Public dan terdaftar di BEI wajib menyampaikan laporan keuangan setiap tahunannya. Tetapi akan lebih baik jika tidak hanya melakukan laporan tahunan yang sifatnya wajib melainkan juga laporan kuartal yang dilakukan 3 (tiga) bulan sekali serta menggunakan jasa notaris. Hal ini akan meningkatkan perspektif investor terhadap perusahaan tersebut dan melihat bahwa perusahaan ini benar-benar menerapkan good government.

Bagi notaris, wajib untuk menerapkan prinsip mengenali pengguna jasanya seperti yang disebutkan dalam pasal 2 angka 1 Peraturan Menteri Hukum dan Hak Asasi Manusia Republik Indonesia Nomor 9 Tahun 2017 tentang Penerapan Prinsip Mengenali Pengguna Jasa bagi Notaris. Prinsip mengenali Pengguna Jasa sebagaimana dimaksud adalah paling sedikit memuat:

1) identifikasi Pengguna Jasa;

2) verifikasi Pengguna Jasa; dan

3) pemantauan Transaksi Pengguna Jasa.

Penerapan Prinsip Mengenali Pengguna Jasa sebagaimana dimaksud pada ayat (2) berlaku bagi Notaris dalam memberikan jasa berupa mempersiapkan dan melakukan transaksi untuk kepentingan atau untuk dan atas nama Pengguna Jasa, mengenai: 
1) pembelian dan penjualan properti;

2) pengelolaan terhadap uang, efek, dan/atau produk jasa keuangan lainnya;

3) pengelolaan rekening giro, rekening tabungan, rekening deposito, dan/atau rekening efek;

4) pengoperasian dan pengelolaan perusahaan; dan/atau;

5) pendirian, pembelian, dan penjualan badan hukum.

Apabila terdapat Pengguna Jasa atau Pemilik Manfaat (Beneficial Owner) yang memiliki tingkat risiko terjadinya tindak pidana pencucian uang atau pendanaan terorisme tergolong berisiko tinggi, Notaris wajib melakukan identifikasi lebih mendalam dan wajib melakukan verifikasi terhadap informasi dan Dokumen yang berkaitan dengan pengguna jasa serta dapat meminta keterangan kepada Pengguna Jasa untuk mengetahui kebenaran formil Dokumen.

Pasal 24 PerMenKumHam no. 9 tahun 2017 menyatakan bahwa untuk itu Notaris wajib memutuskan hubungan usaha dengan Pengguna Jasa jika:

Pengguna Jasa menolak untuk mematuhi prinsip mengenali Pengguna Jasa; atau

Notaris meragukan kebenaran informasi yang disampaikan oleh Pengguna Jasa.

Notaris wajib melaporkan kepada

Pusat Pelaporan dan Analisis Transaksi Keuangan (PPATK) mengenai tindakan sebagaimana dimaksud di atas sebagai Transaksi Keuangan Mencurigakan.

Dengan demikian peran yang dimiliki notaris ini bersifat preventif (pencegahan) atau dengan kata lain adalah tidak secara aktif berperan melindungi investor artinya notaris tidak secara langsung melindungi investor karena notaris sendiri tidak bertanggung jawab atas perlindungan investor tersebut, tetapi notaris hadir sebagai profesi penunjang pasar modal yang dinilai penting untuk membuat akta-akta ataupun perjanjian-perjanjian serta hadir untuk meneliti setiap keabsahan hal-hal yang berkaitan dengan akta atau perjanjian yang dibuatnya. Sehingga memuat fakta dan keadaan yang sebenarnya yang dapat mempengaruhi nilai saham perusahaan tersebut.

Jika pihak yang merasa dirugikan tidak mampu membuktikan ketidakbenaran dari aspek formal dan materil akta notaris, maka akta yang dibuat oleh notaris tersebut tetap berkekuatan sebagai akta otentik, dan masih berlaku terhadap para pihak/penghadap. Namun apabila yang terjadi adalah sebaliknya, pihak yang merasa dirugikan mampu membuktikan ketidakbenaran dari aspek formal dan materil akta notaris, maka akta yang dibuat oleh notaris tersebut hanya akan mempunyai kekuatan pembuktian sebagaimana akta di bawah tangan.

Tanggung jawab notaris di dalam melaksanakan perannya adalah terbatas hanya pada akta yang dibuatnya, dan tidak bertanggung jawab atas kerugian yang diakibatkan karena hal-hal diluar akta tersebut. Menurut Pasal 1 angka 1 UUPT, bahwa akta merupakan alat bukti terkuat dan terpenuhi sehingga tujuan hukum mengintegrasikan dan mengkordinasikan berbagai kepentingan dalam masyarakat tidak melampaui batasan tanggung jawab dari jabatan notaris dalam batasan kewenangannya.

\section{KESIMPULAN DAN SARAN}

Otoritas Jasa Keuangan sebagai lembaga pengawas pasar modal berperan dalam perlindungan hukum terhadap investor baik secara preventif maupun represif. Secara preventif OJK mempunyai fungsi menyelenggarakan sistem pengaturan dan pengawasan yang terintegrasi terhadap 
keseluruhan kegiatan di sektor jasa keuangan, seperti yang telah dijabarkan dalam pasal 5 UU No. 21 tahun 2011, sedangkan secara represif, OJK berwenang memeriksa, melakukan penyidikan dan menerapkan sanksi bagi setiap pihak melakukan pelanggaran. Selain OJK, BEI juga memiliki peranan secara preventif dalam melindungi investor dengan menemukan hal-hal yang berpotensi merugikan investor berupa: Unusual Market Activity (UMA), Efek Tidak Dijamin (ETD), Transaksi Dipisahkan (TD) serta Suspensi yang diumumkan BEI dalam situs resminya sehingga investor dapat mengetahui informasi tersebut dan dapat mengantisipasi dalam mempertimbangkan kelayakan untuk membeli saham atau efek di perusahaan tersebut.

Peran yang dimiliki notaris ini bersifat preventif (pencegahan) atau dengan kata lain adalah tidak secara aktif berperan melindungi investor artinya notaris tidak secara langsung melindungi investor karena notaris sendiri tidak bertanggung jawab atas perlindungan investor tersebut, tetapi notaris hadir sebagai profesi penunjang pasar modal yang dinilai penting untuk membuat akta-akta ataupun perjanjian-perjanjian serta hadir untuk meneliti setiap keabsahan hal-hal yang berkaitan dengan akta atau perjanjian yang dibuatnya. Sehingga memuat fakta dan keadaan yang sebenarnya yang dapat mempengaruhi nilai saham perusahaan tersebut.

Saran, bagi investor yang akan berkomitmen untuk berinvestasi di pasar modal ada baiknya memahami dengan benar tentang resiko yang akan dihadapi serta mencari informasi dengan seksama tentang perusahaan yang akan dibeli sahamnya guna menghindari kerugian di masa depan. Untuk itu Bursa Efek Indonesia sebagai penyelenggara diharapkan memberikan penyuluhan secara terintegrasi dan profesional.
Pengaturan tentang perlindungan investor hendaknya dinyatakan dengan tegas dalam undang-undang pasar modal. Selain itu hendaknya undang-undang nomor 8 tahun 1995 tentang Pasar Modal direvisi karena pada saat ini pengawas pasar modal bukan lagi BAPEPAM melainkan OJK. Sehingga isi Undang-undang tersebut sudah tidak sesuai dengan keadaan saat ini. 


\section{DAFTAR PUSTAKA}

\section{BUKU}

Bismar Nasution. 2001. Keterbukaan dalam Pasar Modal. Jakarta: Fakultas Hukum Universitas Indonesia, Cet. Pertama.

Hasan Zein Mahmud. 1998. Catatan Kolom Hasan Zein. Buku Pertama. Jakarta: Go Global Book.

Irsan Nasarudin dan Indra Surya. 2007. Aspek Hukum Pasar Modal Indonesia. Jakarta: Kencana Prenada Media Group

Najib A. Gisymar. 1999. Insider Trading dalam Transaksi Efek. Bandung: Citra Aditya Bakti.

Soerjono Soekanto dan Sri Mamuji. 1984. Penelitian Hukum Normatif, Jakarta: Rajawali

Suharjono. 1995. Sekilas Tinjauan Akta Menurut Hukum. Jakarta: Sinar Grafika

Tan Thong Kie. 1994. Studi Notariat dan Serba-Serbi Praktek Notaris, Jakarta: Ichtiar Baru Van Hoeve.

Yahya Harahap, 2011. Hukum Perseroan Terbatas, Cet 3 Jakarta: Sinar Grafika.

\section{JURNAL}

Deviana Yuanitasari, The Role Of Public Notary in Provinding Legal Protection on Standart Contract For Indonesian Consumers, Sriwijaya Law Riview, Fakultas Hukum Universitas Sriwijaya, Volume 1 Issue 2, July 2017, hlm 180

Hilda Hilmiah Dimyati. 2014. Perlindungan Hukum Bagi Investor Dalam Pasar Modal. Jurnal Cita Hukum, Vol. I No. 2 Desember 2014

John C. Coffe, Jr. 1984. "Market Failure And The Economic Case For A Mandatory Disclosure System “.
Virginia Law Review. Vol. 70. hlm. 737

Neni Sri Imantiati dan Diana Wiyanti. 2000. Perlindungan Hukum Terhadap Investor Dan Upaya Bapepam Dalam Mengatasi Pelanggaran Dan Kejahatan Pasar. Mimbar No. 4Th.XVI Okt.-Des.2000.

PERATURAN

PERUNDANG-

\section{UNDANGAN}

Lampiran Keputusan Direksi PT Kliring Penjaminan Efek Indonesia Nomor : Kep-011/DIR/KPEI/1215 Tanggal: 28-12-2015, Peraturan Kpei Nomor: Ii-15 tentang Kliring Dan Penjaminan Penyelesaian Transaksi Efek Tidak Dijamin Dan Transaksi Dipisahkan Atas Efek Bersifat Ekuitas.

Undang-undang nomor 2 Tahun 2014 tentang Perubahan atas Undang-undang Nomor 30 Tahun 2004 tentang Jabatan Notaris

\section{WEBSITE}

Kejahatan Pasar Modal Yang Merugikan Investor di Indonesia. 2016. https://www.finansialku.com/kejaha tan-pasar-modal-yang-merugikaninvestor-di-indonesia/ diakses pada tanggal 10 Februari 2018.

Bursa Efek Indonesia. http://www.idx.co.id/investor/perlin dungan-investor/ diakses tanggal 04 Juli 2018. 